DOI : 10.24198/jnttip.v2i1.26670

jurnal.unpad.ac.id/jnttip; e-ISSN:2715-7636

Jurnal Nutrisi Ternak Tropis dan IImu Pakan

2(1):51-59, Maret 2020

\title{
STUDI POTENSI EKSTRAK KULIT MANGGIS (Garcinia mangostana \\ L.) YANG DI SUPLEMENTASI MINERAL TEMBAGA DAN SENG TERHADAP PEMANFAATAN RANSUM AYAM SENTUL
}

\section{Study of The Potential of Mangosteen Peel Extract (Garcinia mangostana L.) Supplemented by Cooper and Zinc on The Utilization of Ration in Sentul Chicken}

\author{
Maulana Yusuf Abdullah', Afif Muhammad ${ }^{1}$, Indrawati Yudha Asmara ${ }^{2}$, Tuti \\ Widjastuti $^{2}$, Hendi Setiyatwan ${ }^{2}$
}

${ }^{1}$ Program Sarjana Ilmu Peternakan, Fakultas Peternakan, Universitas Padjadjaran Kampus Jatinagor, Jl. Raya Bandung-Sumedang KM.21

Jatinangor-Sumedang, Jawa Barat 45363

${ }^{2}$ Departemen Nutrisi Ternak dan Teknologi Ternak Pakan, Fakultas Peternakan, Universitas Padjadjaran. Kampus Jatinangor, J1. Raya Bandung-Sumedang KM.21, JatinangorSumedang, Jawa Barat 45363

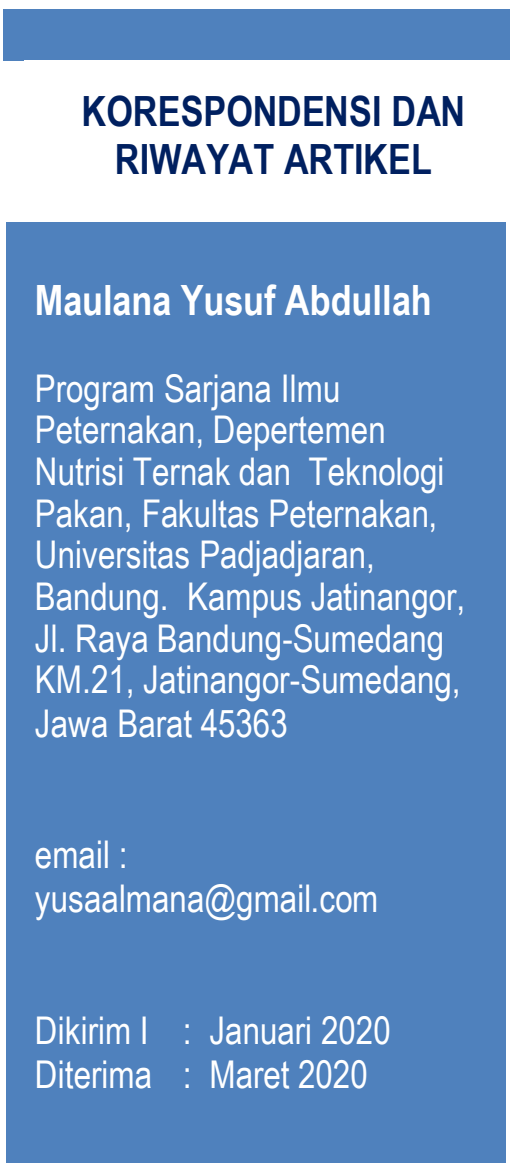

\begin{abstract}
ABSTRAK
Tujuan penelitian untuk mengetahui pengaruh penambahan ekstrak kulit manggis (Garcinia mangostana L.) yang di suplemetasi mineral tembaga dan seng terhadap imbangan efisiensi protein, kecernaan bahan kering, bahan organik, protein pada ayam Sentul. Penelitian dilakukan secara eksperimental menggunakan Rancangan Acak Lengkap (RAL) dengan 5 perlakuan dan 4 ulangan, yaitu P0 (ransum basal), $\mathrm{P} 1$ (P0 + ekstrak kulit manggis (EKM) $60 \mathrm{mg} / \mathrm{kg}+$ $\mathrm{CuSO}_{4}$ 0,3 mg/kg $\left.+\mathrm{ZnO} 2,4 \mathrm{mg} / \mathrm{kg}\right), \mathrm{P} 2(\mathrm{P} 0+\mathrm{EKM} 120$ $\left.\mathrm{mg} / \mathrm{kg}+\mathrm{CuSO}_{4} 0,6 \mathrm{mg} / \mathrm{kg}+\mathrm{ZnO} 4,8 \mathrm{mg} / \mathrm{kg}\right) \mathrm{P} 3$ (P0 + EKM $180 \mathrm{mg} / \mathrm{kg}+\mathrm{CuSO}_{4} 0,9 \mathrm{mg} / \mathrm{kg}+\mathrm{ZnO} 7,2 \mathrm{mg} / \mathrm{kg}$ ), dan $\mathrm{P} 4$ $\left(\mathrm{PO}+\mathrm{EKM} 240 \mathrm{mg} / \mathrm{kg}+\mathrm{CuSO}_{4} 1,2 \mathrm{mg} / \mathrm{kg}+\mathrm{ZnO} 9,6\right.$ $\mathrm{mg} / \mathrm{kg}$ ). Data dianalisis mengunakan Analisis Ragam dan Uji Duncan. Hasil penelitian menunjukan bahwa penambahan ekstrak kulit manggis nyata meningkatkan nilai imbangan efisiensi protein, kecernaan bahan kering, bahan organik dan protein pada ayam Sentul. Disimpulkan bahwa penambahan ekstrak kulit manggis $120 \mathrm{mg} / \mathrm{kg}$ ransum yang di suplementasi $\mathrm{CuSO}_{4} 0,6 \mathrm{mg} / \mathrm{kg}$ ransum dan $\mathrm{ZnO}$ 4,8 $\mathrm{mg} / \mathrm{kg}$ ransum menghasilkan nilai imbangan efisiensi protein 1,61, kecernaan bahan kering 75,11\% , bahan organik $78,64 \%$ dan protein $75,34 \%$.
\end{abstract}

Kata Kunci: manggis, ayam sentul, kecernaan 


\section{ABSTRACT}

The research was aimed to determine the effect of mangosteen peel extract (Garcinia mangostana L.) in ration supplemented by copper and zinc minerals on protein efficiency ratio, dry matter digestibility, organic matter digestibility, protein digestibilty of Sentul chickens. The research was an experimental method used Completely Randomized Design (CRD) with 5 treatments and 4 replications. The treatments were $P 0$ (control ration), $P 1(P 0+$ mangosteen peel extract (MPE) $\left.60 \mathrm{mg} / \mathrm{kg}+\mathrm{CuSO}_{4} 0,3 \mathrm{mg} / \mathrm{kg}+\mathrm{ZnO} 2,4 \mathrm{mg} / \mathrm{kg}\right), \mathrm{P} 2(\mathrm{PO}+\mathrm{MPE} 120 \mathrm{mg} / \mathrm{kg}$ $\left.+\mathrm{CuSO}_{4} 0,6 \mathrm{mg} / \mathrm{kg}+\mathrm{ZnO} 4,8 \mathrm{mg} / \mathrm{kg}\right) \mathrm{P3}\left(\mathrm{PO}+\mathrm{MPE} 180 \mathrm{mg} / \mathrm{kg}+\mathrm{CuSO}_{4} 0,9 \mathrm{mg} / \mathrm{kg}+\mathrm{ZnO}\right.$ $7,2 \mathrm{mg} / \mathrm{kg})$ and $\mathrm{P} 4\left(\mathrm{PO}+\mathrm{MPE} 240 \mathrm{mg} / \mathrm{kg}+\mathrm{CuSO}_{4} 1,2 \mathrm{mg} / \mathrm{kg}+\mathrm{ZnO} 9,6 \mathrm{mg} / \mathrm{kg}\right.$. The results showed that the addition of mangosteen peel extract significantly increased the value of protein efficiency ratio, dry matter digestibility, organic matter and protein in Sentul chicken. It was concluded that the addition of mangosteen peel extract $120 \mathrm{mg} / \mathrm{kg}$ ration supplemented with $\mathrm{CuSO} 40,6 \mathrm{mg} / \mathrm{kg}$ ration and $\mathrm{ZnO} \mathrm{4,8} \mathrm{mg} / \mathrm{kg}$ ration produce value of protein efficiency ration 1,61, dry matter digestibility 75,11\%, organic matter digestibility 78,64\% and protein digestibility $75,34 \%$.

Keywords: mangosteen; Sentul chicken; digestibility

\section{PENDAHULUAN}

Ayam Sentul merupakan ayam lokal yang berasal dari Kabupaten Ciamis. Ayam Sentul merupakan ayam tipe dwiguna yang dapat diarahkan produksinya untuk daging ataupun telur. Keunggulan Ayam Sentul yaitu pertumbuhannya relatif cepat dan produksi telur tinggi (Hidayat dan Sopiyana, 2010). Pengembangan ayam Sentul juga dilakukan untuk menggali dan memaksimalkan potensinya.

Feed additive sering ditambahkan ke dalam ransum untuk mempercepat pertumbuhan serta meningkatkan penyerapan nutrien. Feed additive yang umum digunakan yaitu antibiotik, probiotik, prebiotik, enzim, asam organik dan bioaktif tanaman (Sinurat, dkk. 2003). Antibiotik sudah mulai ditinggalkan karena dampak negatif yang ditimbulkan. Senyawa biokatif asal tanaman sering ditambahkan sebagai feed additive yang mempunyai mekanisme kerja tertentu. Salah satunya tanaman yang bisa digunakan adalah tanaman manggis.

Pemilihan kulit manggis sebagai imbuhan pakan didasarkan kepada ketersediaannya. Manggis merupakan tanaman yang berasal dari hutan tropis di Asia Tenggara termasuk Indonesia sehingga manggis mudah didapatkan. Senyawa bioaktif dalam kulit manggis adalah senyawa xanton (Jung, et al., 2006) yang dapat berfungsi sebagai anioksidan dan antibakteri (Weecharangsan, et al., 2006; Sakagami, et al., 2005)

Ekstraksi diperlukan untuk memisahkan senyawa bioaktif xanton dari kulit manggis. Xanton merupakan senyawa fenol yang termasuk ke dalam golongan flavonoid. Senyawa fenol memiliki sejumlah gugus hidroksi sehingga cenderung bersifat polar (Harbone. 2006). Pelarut etanol merupakan pelarut universal (Snyder, 1997) sehingga berbagai senyawa yang bersifat polar ataupun non polar dapat tertarik ke dalam pelarut.

Ekstrak kulit manggis ditambahkan sebagai feed addtive dalam ransum untuk menjaga kesehatan ternak. Kondisi demikian akan memudahkan ternak dalam menyerap nutrien dalam ransum. Radikal bebas merupakan molekul yang tidak stabil dan dapat menimbulkan reaksi oksidasi, rekasi tersebut dapat menimbulkan kerusakan pada sel. Antioksidan berperan dalam mencegah atau menghambat reaksi oksidasi yang disebabkan oleh radikal bebas dengan cara mendonorkan elektron pada substansi radikal bebas.

Suplementasi mineral mikro seperti tembaga dan seng dapat memaksimalkan aktivitas enzim pertumbuhan (Tanuwiria, 
2004; Tanuwira dkk., 2011) dan kekebalan tubuh.Mineral tembaga dapat meningkatkan kekebalan tubuh dan penyerapan nutrien. Mineral tembaga secara sistematik
Ternak yang digunakan pada penelitian ini adalah ayam Sentul berjumlah 100 ekor yang diperoleh dari Balai Pengembangan Perbibitan Ternak Unggas

Tabel 1. Kandungan Nutrien dan Energi Metabolis Ransum

\begin{tabular}{lcc}
\hline Kandungan Nutrien & Jumlah & Kebutuhan Ayam Lokal \\
\hline Energi Metabolis (kkal/kg) & 2781 & $2750 *$ \\
Protein $(\%)$ & 17.04 & $17 *$ \\
Lemak (\%) & 5,92 & Maks $7 * *$ \\
Serat Kasar (\%) & 4,51 & Maks 7** \\
Kalsium (\%) & 1,16 & Min $0,9 * *$ \\
Fosfor (\%) & 0,36 & Min $0,3 * *$ \\
Lisin $(\%)$ & 1,21 & Min $0,9 * *$ \\
Methionin $(\%)$ & 0,40 & Min 0,30** \\
\hline
\end{tabular}

Sumber: Hasil Analisis Proksimat Laboratorium Nutrisi Ternak Ruminansia dan Kimia Makanan Ternak

*Widjastuti (1996)

**SNI (2008)

mempengaruhi sistem pengaturan pertumbuhan (Klasing, et al., 1989). Mineral seng berperan sebagai kofaktor enzim pertumbuhan dan metabolisme (Tanuwiria dkk., 2007). Mineral Zn mempunyai aktivitas yang mengatur lebih dari 90 enzim dalam tubuh (Linder, 2006). Keberhasilan pemanfaatan ekstrak kulit manggis yang disuplementasi mineral tembaga dan seng dalam ransum ayam Sentul dapat diukur dengan menghitung nilai imbangan efisiensi protein yang menunjukan seberapa efisien protein yang dimanfaatkan untuk mencapai bobot badan tertentu.

Selain itu, pengukuran kecernaan bahan kering, bahan organik dan protein dilakukan untuk melihat kemampuan ternak dalam mencerna nutrien dalam ransum. Oleh karena itu penelitian ini bertujuan untuk mengetahui potensi pemanfaatan ekstrak kulit manggis yang disuplementasi mineral tembaga dan seng.

\section{METODE PENELITIAN}

\section{Ternak Percobaan}

(BPPTU) Majalengka. Kandang yang digunakan merupakan kandang terbuka dengan sistem litter sebanyak 20 unit dengan ukuran panjang, lebar dan tinggi secara berturut-turut adalah $1 \mathrm{~m}$ x $0,75 \mathrm{~m}$ x 0,5 m dilengkapi dengan ram kawat.

\section{Pembuatan Ekstrak}

Ekstraksi kulit manggis menggunakan metode maserasi yang terdiri atas beberapa tahap diantaranya perendaman, penyaringan, penguapan (evaporasi) dan pengeringan. Proses pembuatan ekstrak kulit manggis diawali dengan perendaman tepung kulit manggis dengan etanol $96 \%$ dalam waktu 2 x 24 jam, kemudian di saring dan dimasukan ke dalam wadah sehingga didapatkan ekstrak kulit manggis yang masih tercampur dengan etanol. Ekstrak kulit manggis etanol dimasukan pada alat evaporator untuk dilakukan proses evaporasi dengan suhu $60^{\circ} \mathrm{C}$, Tujuan proses evaporasi untuk memisahkan etanol dengan ekstrak kulit manggis. Selanjutnya dilakukan pengeringan menggunakan oven pada suhu $50^{\circ} \mathrm{C}$ sehingga didapatkan ekstrak kulit manggis dalam bentuk tepung. 


\section{Ransum Basal dan Perlakuan}

Susunan ransum basal yang digunakan terdiri atas dedak halus, jagung kuning, bungkil kedelai, tepung ikan, tepung tulang dan kapur $\left(\mathrm{CaCO}_{3}\right)$. Komposisi bahan pakan yang digunakan berasal dari Poultry Shop Missouri Bandung. Susunan ransum basal didasarkan pada kebutuhan protein kasar dan energi metabolis ayam Sentul pada fase starter. Widjastuti (1996) menyatakan ransum ayam Sentul pada fase starter memiliki kandungan protein kasar $17 \%$ dan energi metabolis $2750 \mathrm{kkal} \mathrm{EM} / \mathrm{Kg}$. Kandungan nutrien dan energi metabolis dari ransum yang digunakan dicantumkan pada Tabel 1 .

Pemeliharaan dilakukan selama 12 minggu. Ransum yang diberikan dalam bentuk mash dan pellet. Data yang diukur di lapangan adalah konsumsi ransum dan pertambahan bobot badan (PBB). Konsumsi ransum di ukur setiap hari dan pertambahan bobot badan diukur setiap 1 minggu sekali. Data yang diukur di laboratorium adalah bahan kering ransum dan feses, bahan organik ransum dan feses, protein ransum dan feses. Peubah yang diamati antara lain imbangan efisiensi protein (IEP), konsumsi protein, kecernaan bahan kering, kecernaan bahan organic, kecernaan protein kasar.

Penelitian dilakukan secara eksperimental dengan rancangan yang digunakan adalah rancangan acak lengkap dengan 5 perlakuan dan 4 ulangan. Adapun perlakuan adalah sebagai berikut: $\mathrm{P} 0=$ Ransum basal; P1 = Ransum basal + ekstrak kulit manggis $60 \mathrm{mg} / \mathrm{kg}$ ransum yang di suplementasi $\mathrm{CuSO}_{4} 0,3 \mathrm{mg} / \mathrm{kg}$ ransum dan $\mathrm{ZnO} 2,4 \mathrm{mg} / \mathrm{kg}$ ransum; P2 = Ransum basal + ekstrak kulit manggis $120 \mathrm{mg} / \mathrm{kg}$ ransum yang di suplementasi $\mathrm{CuSO}_{4} \quad 0,6 \mathrm{mg} / \mathrm{kg}$ ransum dan $\mathrm{ZnO} 4,8 \mathrm{mg} / \mathrm{kg}$ ransum; $\mathrm{P} 3=$ Ransum basal + ekstrak kulit manggis 180 $\mathrm{mg} / \mathrm{kg}$ ransum yang di suplementasi $\mathrm{CuSO}_{4}$ $0,9 \mathrm{mg} / \mathrm{kg}$ ransum dan $\mathrm{ZnO} 7,2 \mathrm{mg} / \mathrm{kg}$ ransum; P4 = Ransum basal + ekstrak kulit manggis $240 \mathrm{mg} / \mathrm{kg}$ ransum yang di suplementasi $\mathrm{CuSO}_{4} 1,2 \mathrm{mg} / \mathrm{kg}$ ransum dan $\mathrm{ZnO} 9,6 \mathrm{mg} / \mathrm{kg}$ ransum.

Data yang terkumpul selanjutnya dilakukan analisis dengan uji jarak berganda duncan (Gasperz. 2006)

\section{HASIL DAN PEMBAHASAN}

Setelah dilakukan penelitian dengan perlakuan penambahan ekstrak kulit manggis yang disuplementasi mineral tembaga dan seng dalam ransum dapat diperoleh rataan konsumsi ransum, konsumsi protein, pertambahan bobot badan dan imbangan efisiensi protein yang disajikan pada Tabel 2.

Hasil analisis ragam menunjukan bahwa terdapat perbedaan yang nyata $(\mathrm{P}<0,05)$ antara perlakuan pada berbagai tingkat penambahan ekstrak kulit manggis yang disuplementasi mineral tembaga dan seng terhadap imbangan efisiensi protein pada ayam Sentul.

Konsumsi protein pada ayam Sentul dengan penambahan ekstrak kulit manggis yang disuplementasi mineral tembaga dan seng pada setiap perlakuan tidak berbeda nyata. Tillman, dkk. (1998) menyatakan bahwa konsumsi protein dipengaruhi jumlah ransum yang dikonsumsi, juga dipengaruhi oleh kandungan protein dan energi metabolis yang terdapat dalam ransum. Hasil analisis ragam menunjukan bahwa konsumsi ransum tidak berbeda nyata $(\mathrm{P}>0,05)$ pada setiap perlakuan. Hal demikian menyebabkan konsumsi protein pun tidak berbeda pada setiap perlakuan.

Wahju (2013) menyatakan bahwa konsumsi ransum dipengaruhi oleh beberapa faktor diantaranya suhu lingkungan, umur, jenis kelamin, bangsa, imbangan nutrien dalam ransum, kecepatan pertumbuhan, tingkat produksi, bobot badan, palatabilitas dan tingkat energi metabolis ransum. Semakin tinggi energi metabolis dalam ransum maka konsumsi ransum menurun begitupun sebaliknya Pemberian ekstrak kulit manggis yang di suplementasi mineral tembaga dan seng 
tidak berpengaruh terhadap konsumsi protein. Hal demikian menunjukan bahwa semua ransum yang diberikan memiliki palatabilitas yang sama serta memiliki pertumbuhan bakteri patogen yang dapat menyebabkan penyakit pada ternak.

Suplementasi mineral tembaga dan seng dapat membantu peran senyawa

Tabel 2. Rataan Kecernaan Bahan Kering, Kecernaan Bahan Organik, Kecernaan Protein, Konsumsi Ransum, Konsumsi Protein, Pertambahan Bobot Badan dan Imbangan Efisiensi Protein pada Ayam Sentul

\begin{tabular}{lrrrrr}
\hline \multirow{2}{*}{ Peubah yang Diamati } & \multicolumn{5}{c}{ Perlakuan } \\
\cline { 2 - 6 } & \multicolumn{1}{c}{ P0 } & P1 & P2 & P3 & P4 \\
\hline Kecernaan Bahan Kering (\%) & $70,04^{\mathrm{a}}$ & $70,54^{\mathrm{a}}$ & $75,11^{\mathrm{b}}$ & $73,06^{\mathrm{ab}}$ & $69,54^{\mathrm{a}}$ \\
Kecernaan Bahan Organik (\%) & $73,59^{\mathrm{a}}$ & $74,61^{\mathrm{ab}}$ & $78,64^{\mathrm{b}}$ & $77,49^{\mathrm{ab}}$ & $73,68^{\mathrm{a}}$ \\
Kecernaan Protein (\%) & $67,22^{\mathrm{a}}$ & $70,73^{\mathrm{a}}$ & $75,34^{\mathrm{b}}$ & $70,01^{\mathrm{a}}$ & $68,33^{\mathrm{a}}$ \\
Konsumsi Ransum (g/ekor) & $2637,65^{\mathrm{a}}$ & $2643,20^{\mathrm{a}}$ & $2569,15^{\mathrm{a}}$ & $2671,09^{\mathrm{a}}$ & $2723,3^{\mathrm{a}}$ \\
Konsumsi Protein (g/ekor) & $448,40^{\mathrm{a}}$ & $449,34^{\mathrm{a}}$ & $436,75^{\mathrm{a}}$ & $454,08^{\mathrm{a}}$ & $462,96^{\mathrm{a}}$ \\
Pertambahan BB (g/ekor) & $631,70^{\mathrm{a}}$ & $660,00^{\mathrm{a}}$ & $700,85^{\mathrm{a}}$ & $633,75^{\mathrm{a}}$ & $605,39^{\mathrm{a}}$ \\
Imbangan Efisiensi Protein & $1,409^{\mathrm{a}}$ & $1,469^{\mathrm{ab}}$ & $1,610^{\mathrm{b}}$ & $1,407^{\mathrm{a}}$ & $1,308^{\mathrm{a}}$ \\
\hline Keterangan : Superskrp yang betben
\end{tabular}

Keterangan : Superskrip yang berbeda kearah baris yang sama menunjukan pengaruh berbeda nyata $(\mathrm{P}<0,05)$

kandungan protein kasar dan energi metabolis yang sama.

Imbangan efisiensi protein pada perlakuan penambahan ekstrak kulit manggis $120 \mathrm{mg} / \mathrm{kg}$ ransum yang di suplementasi $\mathrm{CuSO}_{4} 0,6 \mathrm{mg} / \mathrm{kg}$ ransum dan $\mathrm{ZnO} 4,8 \mathrm{mg} / \mathrm{kg}$ ransum (P2) menghasilkan nilai imbangan efisiensi protein yang paling tinggi. Nilai imbangan efisiensi protein dipengaruhi oleh pertambahan bobot badan dan konsumsi protein (Khodijah, dkk. 2012). Tingginya nilai imbangan efisiensi protein pada perlakuan P2 disebabkan oleh senyawa bioaktif xanton yang berfungsi dalam menjaga kesehatan ternak. Xanton berperan sebagai antioksidan (Weecharangsan, et al., 2006) dan antibakteri (Sakagami, et al., 2005). Antioksidan berperan dalam menjaga kesehatan ternak, kondisi demikian akan memudahkan ternak dalam menyerap nutrien dari ransum. Xanton memiliki sifat antibakteri sehingga dapat menekan bioaktif xanton dengan cara menjaga kekebalan tubuh dan meningkatkan metabolisme nutrien pada ternak. Menurut Klasing, et al. (1989) mineral tembaga berperan dalam menjaga kekebalan tubuh dan meningkatkan penyerapan nutrien. Menurut Piliang (1997) mineral seng berfungsi sebagai kofaktor enzim protease dan karboksi peptidase yang berperan dalam metabolisme protein.

Nilai imbangan efisiensi protein menurun pada perlakuan penambahan ekstrak kulit manggis $180 \mathrm{mg} / \mathrm{kg}$ ransum yang di suplementasi $\mathrm{CuSO}_{4} \quad 0,9 \mathrm{mg} / \mathrm{kg}$ ransum dan $\mathrm{ZnO} 7,2 \mathrm{mg} / \mathrm{kg}$ ransum (P3) dan perlakuan penambahan ekstrak kulit manggis $240 \mathrm{mg} / \mathrm{kg}$ ransum yang di suplementasi $\mathrm{CuSO}_{4} 1,2 \mathrm{mg} / \mathrm{kg}$ ransum dan $\mathrm{ZnO} 9,6 \mathrm{mg} / \mathrm{kg}$ ransum (P4). Hal demikian diduga karena kadar tanin yang terdapat pada ekstrak kulit manggis semakin tinggi. Veggi, et al. (2013) menyatakan ekstraksi dapat menurunkan kadar tanin tetapi 
tergantung kepada lama waktu ekstraksi. Widodo (2004) menyatakan bahwa tanin dapat menghambat kerja enzim pencernaan dan mempunyai kemampuan untuk mengikat protein di usus halus.

Perlakuan penambahan ekstrak kulit manggis $120 \mathrm{mg} / \mathrm{kg}$ ransum yang di suplementasi $\mathrm{CuSO}_{4} 0,6 \mathrm{mg} / \mathrm{kg}$ ransum dan $\mathrm{ZnO} 4,8 \mathrm{mg} / \mathrm{kg}$ ransum (P2) menghasilkan nilai kecernaan bahan kering tertinggi yaitu $75,11 \%$. Hal ini disebabkan xanthone yang terkandung pada ekstrak kulit manggis dapat berfungsi sebagai antibakteri dan antioksidan yang dapat menjaga kesehatan dan struktur vili-vili usus sehingga penyerapan nutrien dapat maksimal. Sejalan dengan pernyataan Velmurugan dan Citrasu (2010) bahwa zat aktif xanthone mempunyai fungsi sebagai antioksidan, antivirus, antijamur, dan antimikrobial, yang diduga mampu memperbaiki struktur vili-vili usus dalam proses penyerapan zat nutrien (Mushawwir et al., 2017) dan mampu menekan pertumbuhan bakteri patogen dalam usus (Mushawwir et al, 2018; Dinana dkk., 2019).

Kecernaan bahan organik pada perlakuan penambahan ektrak kulit manggis sebanyak $120 \mathrm{mg} / \mathrm{kg}$ ransum yang di suplementasi $\mathrm{CuSO}_{4}$ 0,6 mg/kg ransum dan $\mathrm{ZnO} 4,8 \mathrm{mg} / \mathrm{kg}$ ransum (P2) menghasilkan nilai tertinggi dari semua perlakuan. Kecernaan bahan organik merupakan kecernaan zat-zat yang meliputi komponen bahan organik seperti karbohidrat, protein dan lemak. Senyawa xanthone yang berfungsi sebagai antibakteri pada ektrak kulit manggis dapat menjaga kesehatan usus dan struktur vili-vili usus sehingga dapat meningkat penyerapan nutrien yang terkandung pada ransum.

Kecernaan bahan organik akan meningkat apabila kecernaan bahan kering meningkat. Peningkatan kecernaan bahan organik sejalan dengan meningkatnya kecernaan bahan kering, karena sebagian besar komponen bahan kering terdiri atas bahan organik sehingga faktor-faktor yang mempengaruhi tinggi rendahnya kecernaan bahan kering akan berpengaruh juga terhadap tinggi rendahnya bahan organik (Sutardi, 1980). Mineral $\mathrm{Cu}$ dapat membantu menjaga kesehatan usus karena adanya sifat. Pemberian mineral $\mathrm{Cu}$ membantu menjaga kesehatan usus Ayam Sentul karena $\mathrm{Cu}$ memiliki sifat antimikrobia (Burnell, et al., 1988). Mineral $\mathrm{Zn}$ juga dapat membantu dalam metabolisme komponen bahan organik. Mineral $\mathrm{Zn}$ yang merupakan bagian dari sistem enzim banyak berperan dalam metabolisme karbohidrat, sintesis protein, dan metabolisme asam nukleat (NRC, 1994).

Kecernaan protein pada perlakuan penambahan ektrak kulit manggis sebanyak $120 \mathrm{mg} / \mathrm{kg}$ ransum yang di suplementasi $\mathrm{CuSO}_{4} \quad 0,6 \mathrm{mg} / \mathrm{kg}$ ransum dan $\mathrm{ZnO}$ 4,8 $\mathrm{mg} / \mathrm{kg}$ ransum (P2) menghasilkan kecernaan protein yang paling tinggi. Kecernaan protein dapat dipengaruhi oleh kerja dari enzim-enzim yang mencerna protein. Senyawa xanthone yang terdapat pada ekstrak kulit manggis dapat berfungsi antioksidan. Antioksidan dapat menjaga aktivitas dan kerja enzim pencerna protein dari radikal bebas. Kinanti (2011) menyatakan bahwa radikal bebas dapat menyebabkan gangguan metabolisme dan gangguan sel berupa gangguan fungsi DNA dan protein, sehingga menyebabkan mutasi atau sitotoksik dan perubahan aktivitas enzim.

Senyawa xanthone sebagai antibakteri juga dapat menghambat perkembangan bakteri patogen yang terdapat di dalam usus halus sehingga dapat meningkatkan kecernaan protein kasar.. Pemberian mineral $\mathrm{Cu}$ dan $\mathrm{Zn}$ membantu dalam menjaga kesehatan usus dan sintesis protein. Mineral $\mathrm{Cu}$ dapat merangsang pertumbuhan karena adanya sifat antimikrobia (Burnell, et al., 1988). Mineral $\mathrm{Zn}$ merupakan kofaktor lebih dari 70 macam enzim (Bernadier, 1998) dimana enzim-enzim tersebut banyak berperan dalam proses metabolisme. Piliang (1997) menyatakan bahwa mineral $\mathrm{Zn}$ berfungsi 
sebagai kofaktor enzim diantaranya enzim protease dan pankreatik karboksipeptidase yang berfungsi dalam metabolisme protein.

\section{SIMPULAN DAN SARAN}

Perlakuan penambahan ekstrak kulit manggis sebanyak $120 \mathrm{mg} / \mathrm{kg}$ ransum yang disuplementasi $\mathrm{CuSO}_{4} \quad 0,6 \mathrm{mg} / \mathrm{kg}$ ransum dan $\mathrm{ZnO} 4,8 \mathrm{mg} / \mathrm{kg}$ ransum menghasilkan nilai imbangan efisiensi protein, kecernaan bahan kering, kecernaan bahan organik, kecernaan protein yang paling tinggi. Perlu dilakukan kajian lebih lanjut mengenai analisis kadar tanin yang terdapat pada ekstrak kulit manggis dan penambahan mineral yang tepat supaya dalam penggunaanya lebih praktis.

\section{UCAPAN TERIMA KASIH}

Ucapan Terima Kasih kami sampaikan kepada pihak yang membantu penelitian ini, khususnya kepada tim Academic Leadership Grant (ALG) yang diketuai oleh Prof. Dr. Ir. Hj. Tuti Widjastuti, MS. yang telah memfasilitasi dan mendanai penelitian ini.

\section{DAFTAR PUSTAKA}

Bernadier, C. D. 1998. Advanced Nutrition of Mikroelement. Boca Raton, Boston, London New York, Washington DC.

Burnell T. W., G. L. Cromwell. and T. S. Stahly. 1998. Bolton Line Nutrition. Feedstufs. 13:16-18.

Crampton, E. W. and L. E. Harris. 1969. Applied Animal Nutrition. W. H. Freeman and Company. San Fransisco.

Dinana, A., D. Latipudin, D. Darwis dan A. Mushawwir. 2019. profil enzim transaminase ayam ras petelur yang diberi kitosan iradiasi. J. Nutrisi Ternak Tropis dan Ilmu Pakan 1:6-15.
Gatenby, R. M. 1986. Sheep Production in The Tropics and Sub-tropics. Longman, London-New York.

Harbone, J. B. 2006. Metode Fitokimia: Penuntun Cara Modern Menganalisis Tumbuhan. Edisi Kedua. Penerbit ITB. Bandung.

Hidayat, C. dan S. Sopiyana. 2010. Potensi Ayam Sentul Sebagai Plasma Nutfah Asli Ciamis Jawa Barat. Balai Penelitian Ternak. Bogor.

Jung, H. A., B.N. Su, W.J. Keller, R.G. Mehta and A.D. Kinghorn. 2006. Antioxidant xanthones from the pericarp of garcinia mangostana (Mangosteen). J. Agric. Food. Chem. 54:2077-2082.

Khodijah, E. S., Abun., R. Wiradimaja. 2012. Imbangan Efisiensi Protein Broiler yang Diberi Ransum Mengandung Ekstrak Kulit Jengkol (Pithecellobium jiringa (Jack) Prain). Fakultas Peternakan, Universitas Padjadjaran, Bandung.

Kinanti, A. S. 2011. Pengaruh suplementasi vitamin $\mathrm{E}$ dan DL- methionine dalam ransum terhadap performa ayam broiler pada kondisi cekaman panas. Skripsi. Departemen Ilmu Nutrisi dan Teknologi Pakan, Fakultas Peternakan, Institut Pertanian Bogor. Bogor.

Klasing, K. C., D. E. Laurin, R. K. Peng, and D. M. Fry. 1989. Immunologically mediated growth depresion in chick; influence of feed intake. Corticosterone and Inter-leukin. J. Nut. 117:1629-1637.

Linder M. C. 2006. Biokimia Nutrisi dan Metabolisme. University Indonesia Press. Jakarta.

Mushawwir, A, U. H. Tanuwiria, K.A. Kamil, L. Adriani and R. Wiradimadja. 2017. Effects of volatile oil of garlic on feed utilization, blood biochemistry and performance of heat-stressed japanese quail. Asian J. of Poult. Sci. 11:83-89. 
Mushawwir, A, U.H. Tanuwiria, K. A. Kamil, L. Adriani, R. Wiradimadja, and N. Suwarno. 2018. Evaluation of haematological responses and blood biochemical parameters of heat-stressed broilers with dietary supplementation of javanese ginger powder (curcuma xanthorrhiza) and garlic extract (Allium sativum). Int. J. of Poult. Sci. 17:452-458.

National Research Council. 1994. Nutrien Requirements of Poultry. $9^{\text {th }}$ ed. National Academy Press, Washington, DC.

Piliang, W. G. 1997. Nutrisi Mineral. Edisi Ke-2. Institut Pertanian Bogor Press. Bogor.

Ranjhan, S.K. 1980. Animal Nutrition in the Tropics. Vikas Publishing Hause P\&T Ltd., New Delhi.

Sakagami Y., M. Iinuma, K. G. Piyasena and H. R. Dharmaratne. 2005. Antibacterial activity of alphamangostin against vancomycin resistant Enterococci (VRE) and synergism with antibiotics. Phytomedicine. 12: 203-8.

Schneider, B. H. and W. P. Flatt. 1975. The Evaluation Of Feeds Through Digestibility Experiment. The University ff Georgia Press. New York. Hal. 12-13.

Sinurat, A. P. T., M. H. Purwadaria, Togatorop, dan T. Pasaribu. 2003. Pemanfaatan bioaktif tanaman sebagai feed additive pada ternak unggas. J. Ilmu Ternak Veteriner. 8:34-39.

Snyder, C. R., J. J. Kirkland, and J. L. Glajach. 1997. Practical HPLC Method Development. Second Edition. John Wiley dan Sons, Lnc. New York.

Sutardi, T. 1980. Landasan Ilmu Nutrisi Jilid 1. Departemen Ilmu Makanan Ternak. Fakultas Pertanian IPB. Bogor.
Tanuwiria, U.H. 2004. Efek suplementasi $\mathrm{Zn}-\mathrm{Cu}$ proteinat dalam ransum terhadap fermentabilitas dan kecernaan in vitro. J. Agroland. 4:712.

Tanuwiria, U.H., U. Santosa, A.A. Yulianti and U. Suryadi. 2011. The Effect of organic-Cr dietary supplementation on stress response in transportstressed beef cattle. J. Indon. Trop. Anim. Agric. 36:97-103.

Tanuwiria, U.T., A. Mushawwir dan A.A. Yulianti. 2007. Potensi pakan serat dan daya dukungnya terhadap populasi ternak ruminansia di wilayah kabupaten Garut. J. Ilmu Ternak. 7:11-16.

Tillman, A. D., H. Hartadi., S. Rekosohadiprodjo,S.Prawirokusumo, dan S. Lebdosukujo. 1998. Ilmu Makanan Ternak Dasar. Cetakan ke 4. Gadjah Mada University Press. Yogyakarta.

Veggi, C., J. Priscilla, Martinez, M. Angela and A. Meireles. 2013. Microwaveassisted Extraction for Bioactive Compounds Theory and Practice. UK.

Velmurugan, S. and T. Citarasu. 2010. Effect of herbal antibacterial extracts on the gut floral changes in indian white shrimp Fenneropenaeus indicus. Rom. Biotech. Lett: 45:57095717.

Wahju, J. 2013. Ilmu Nutrisi Unggas. Cetakan ke-5. Gadjah Mada University Press. Yogyakarta.

Weecharangsan, W., P. Opanasopit, M. Sukma, T. Ngawhirunpat, U. Sotanaphun and P. Siripong. 2006. Antioxidative and Neuroprotective Activities of Extracts from The Fruit Hull of Mangosteen (Garcinia mangostana Linn.). Med. Princ. Pract. 15:281-287.

Widjastuti, T. 1996. Penentuan efisiensi penggunaan protein, kebutuhan protein dan energi untuk pertumbuhan dan produksi telur ayam sentul pada kandang sistem cage litter. Disertasi. 
Program Pascasarjana Unpad. Bandung.

Widodo, W. 2004. Bahan Pakan Unggas

Non Konvensional. Universitas

Muhammadiyah Malang. Malang. 